\title{
Christianity and the encounter of world religions. Considerations to a contemporary theology of religions
}

\author{
Christian Danz ${ }^{*}$
}

\begin{abstract}
A basic problem of the contemporary religious-theological discussion may consist in the task of connecting a methodically sensitive culturalhermeneutical theory of religion with a normative perspective. This task cannot be fairly developed either from theologies of religion oriented by the religious-theological triadic pattern of exclusivism, inclusivism, and pluralism, or from the conceptions of comparative theologies. In my essay, I take up this question and try to show further aspects for the present religious-theological discussion by means of Tillich's lectures on Christianity and the Encounter of the World Religions. His contribution is a threefold one: (1.) Through the methodic assimilation of the concept of religion, the pluralism of religions becomes, in principle, recognized. (2.) The foundation of the history of religions leads to a differentiated perception of the complex interreligious exchange processes. (3.) Tillich's theology of religion involves not only the recognition of religious pluralism, but also a methodological justification for a normative criterion for the evaluation of religions. In the form of six theses, I would like to
\end{abstract}

* Professor of Systematic Theology at the Evangelisch-Theologische Fakultät - Universität Wien. Chairman of the Deutsche Paul-Tillich-Gesellschaft, editor of the F. W. J. Schelling's "Theologische Jugendschriften" and of the Band I, 14 of the "Historischkritischen Ausgabe der Werke F. W. J. Schellings". Amongst Prof. Dr. habil. Christian Danz's innumerous publications, we mention especially Die philosophische Christologie F. W. J. Schellings (Schellingiana, vol. 9, ed. Walter E. Erhardt). Stuttgart-Bad Cannstatt: Frommann-Holzboog, 1996, and Religion als Freiheitsbewußtsein. Eine Studie zur Theologie als Theorie der Konstitutionsbedingungen individueller Subjektivität bei Paul Tillich. Berlin; New York: Walter de Gruyter, 2000. [Prof. Dr. Fábio Henrique de Abreu would like to express his enormous gratitude to Prof. Dr. habil. Christian Danz for making available for publication the present lecture delivered during Abreu's course on German Classical Philosophy at the Hartford Seminary, CT, USA, on November 22 $\left.{ }^{\text {nd }}, 2016.\right]$ 
answer the question of the consequences of what has been said so far for the reflection and treatment of religious pluralism within theology.

Keywords: Religious-theological discussion; Theory of religion; Paul Tillich's theology of religion; Theses on systematic theology and religious pluralism.

\section{Das christentum und die begegnung der weltreligionen. überlegungen zu einer gegenwärtigen theologie der religionen}

\section{ZUSAMMENFASSUNG}

Ein Grundproblem der gegenwärtigen religionstheologischen Diskussion dürfte in der Aufgabe einer methodisch sensiblen Verbindung einer kulturhermeneutischen Religionstheorie mit einer normativen Perspektive liegen. Dieser Aufgabe werden weder die an dem religionstheologischen Dreierschema von Exklusivismus, Inklusivismus und Pluralismus orientierten Religionstheologien noch die Konzeptionen von komparativen Theologien gerecht. In meinem Beitrag nehme ich diese Fragestellung auf und versuche anhand von Tillichs Vorlesungen Das Christentum und die Begegnung der Weltreligionen für die gegenwärtige religionstheologische Diskussion weiterführende Aspekte aufzuzeigen. Sein Beitrag besteht in einem Dreifachen: (1.) Durch die methodische Aufnahme des Religionsbegriffs wird der Pluralismus der Religionen prinzipiell anerkannt. (2.) Die religionsgeschichtliche Grundlegung führt zu einer differenzierten Wahrnehmung der komplexen interreligiösen Austauschprozesse. (3.) Mit Tillichs Religionstheologie ist nicht nur eine Anerkennung des religiösen Pluralismus verbunden, sondern auch eine methodische Begründung eines normativen Kriteriums zur Beurteilung von Religionen. Abschließend möchte ich in Form von sechs Thesen die Frage beantworten, welche Konsequenzen aus dem bisher Gesagten für eine Reflexion und Behandlung des religiösen Pluralismus innerhalb der Theologie zu ziehen sind. Schlüsselwörter: Religionstheologische Diskussion; Religionstheorie; Paul Tillichs Religionstheologie; Thesen über systematische Theologie und religiösen Pluralismus. 


\section{Cristianismo e o encontro das religiões mundiais. considerações para uma teologia das religiões contemporânea}

\section{RESUMO}

Um problema básico da discussão teológico-religiosa contemporânea talvez resida na tarefa de combinar uma teoria da religião embasada numa hermenêutica cultural metodicamente sensível com uma perspectiva normativa. Esta tarefa não pode ser satisfatoriamente desenvolvida nem a partir de teologias da religião orientadas pelo padrão teológico-religioso triádico do exclusivismo, inclusivismo e pluralismo, nem a partir das concepções oriundas das teologias comparativas. Na presente contribuição, eu assumo esta questão e tento demonstrar, a partir das palestras de Tillich sobre o Cristianismo e o Encontro das Religiões Mundiais, aspectos ulteriores para a presente discussão teológico-religiosa. A contribuição de Tillich é tripartite: (1.) Através da assimilação metódica do conceito de religião, o pluralismo das religiões se torna reconhecido em termos de princípio. (2.) O fundamento da história das religiões conduz a uma percepção diferenciada dos complexos processos de câmbio interreligioso. (3.) A teologia da religião de Tillich envolve não somente o reconhecimento do pluralismo religioso, mas também uma justificação metódica para um critério normativo para a valoração das religiões. Por fim, na forma de seis teses, eu gostaria de responder a questão das consequências do que até aqui fora dito para a reflexão e tratamento do pluralismo religioso no âmbito da teologia.

Palavras-chave: Discussão teológico-religiosa; Teoria da religião; Teologia da religião de Paul Tillich; Teses sobre teologia sistemática e pluralismo religioso.

\section{Introduction}

The social development of the last thirty years has led to more attention to the religious pluralism within theology, also in Europe ${ }^{1}$. In

\footnotetext{
See DANZ, C. Einführung in die Theologie der Religionen. Münster; Wien: LIT Verlag, 2005; DANZ, C. Die Deutung der Religion in der Kultur. Aufgaben und Probleme der Theologie im Zeitalter des religiösen Pluralismus. Neukirchen-Vluyn: Neukirchener Verlag, 2008; GRAF, F. W. Die Wiederkehr der Götter. Religion in der modernen Kultur. München: Verlag C. H. Beck, 2007; RIESEBRODT, M. Die Rückkehr der Religionen. Fundamentalismus und der „Kampf der Kulturen“. München: Verlag C. H. Beck, 2000; KNITTER, P. F. Introducing Theologies of Religions. Maryknoll: Orbis Books, 2002.
} 
Germany, a wide religious theological debate emerged as a result of the Anglo-American discussion. A basic problem of theology of religions consists in connecting one's own religious point of view with an unprejudiced acknowledgement of other religions. Taking up this problem, I want to ask whether and how Tillich's theology could provide a solution for it, and which aspect of his thought offers true progress for the contemporary theology of religions discussion. My thesis for discussion is that basic problems of contemporary theology of religions lie in connecting the method of a cultural hermeneutics theory of religion with a normative perspective, since the tripartite scheme of exclusivism, inclusivism and pluralism is not very useful for a theology of religions.

Thus, to give reasons for this thesis, in a first part, we briefly have to deal with the analysis of the contemporary theology of religions debate, and the difficulties which confront us in its represented models. I take the discussion about the tripartite scheme for granted and will not try to integrate Tillich into one of these systems ${ }^{2}$. In a second part, I want to work out the thoughts of Tillich's theology of religions, as developed in his Bampton Lectures, entitled Christianity and the Encounter of the World Religions, and in his last lecture The Significance of the History of Religions for the Systematic Theologian ${ }^{3}$. Finally, I will name those aspects of Tillich's theology of religions which represent true progress in the present contemporary discussion.

2 See JAMES, R. B. Tillich and World Religions. Encountering other Faiths Today. Macon: Mercer University Press, 2003, p. 52-54. See also SCHÜßLER, W. Im „Rhythmus von Kritik, Gegenkritik und Selbstkritik“. Paul Tillich zum Absolutheitsanspruch des Christentums und zum interreligiösen Dialog. Trierer Theologische Zeitschrift, 116, 2007, p. 61-74; STENGER, M. A. Christ Jesus - Centre of History for Whom? Exploring Tillich's Christology for Developing a Critical Pluralism. In: HAIGIS, P.; HUMMEL, G.; LAX, D. (Hrsg.). Christus - Mitte der Geschichte!? Beiträge des X. Internationalen Paul Tillich-Symposions Frankfurt/Main 2004. Berlin: LIT Verlag, 2007, p. 257-269.

3 TILLICH, P. Christianity and the Encounter of World Religions. In: SCHARLEMANN, R. P. (Hrsg.). Main Works - Hauptwerke. Band 5: Religiöse Schriften. Berlin; New York: Walter de Gruyter; Evangelisches Verlagswerk, 1988, p. 291-325; TILLICH, P. The Significance of the History of Religions for the Systematic Theologian. In: HUMMEL, G. (Hrsg.). Main Works - Hauptwerke. Band 6: Theologische Schriften. Berlin; New York: Walter de Gruyter; Evangelisches Verlagswerk, 1992, p. 431-446; TILLICH, P. The Encounter of Religions and Quasi-Religions. Lewiston; Queenston; Lampeter: Edwin Mellen Press, 1990. 


\section{The contemporary debate in theology of religions}

The contemporary debate about the theology of religions primarily discusses three points of departure: the pluralistic model of the theology of religions, forms of a new, mutual inclusivism ${ }^{4}$, and the so-called comparative theology ${ }^{5}$. In the following, I will sketch these models and their difficulties.

John Hick was the first to newly determine the attitude of Christianity to non-Christian religions by overcoming claims of the superiority of Christianity, and by acknowledging non-Christian religions ${ }^{6}$. The main thought of his pluralistic model is a theory of religious experience connected with a categorical differentiation. "We now have to distinguish between the Real an sich and the Real as variously experienced-and-thought by different human communities "'. Religions have to be understood as human responses to the manifestation of the Real "an sich". From this perspective of the Real "an sich", all great world religions are equally valid. Yet, for Hick, their differences and diversities do not result from the manifestation of the Real "an sich", but from their own answers to this revelation, which are influenced by the prevailing culture ${ }^{8}$.

Different objections to the pluralistic model have been raised. Foremost it is the question of how Hick's model is able to acknowledge

4 BERNHARDT, R. Protestantische Religionstheologie auf trinitätstheologischem Grund. In: DANZ, C.; KÖRTNER, U. H. J. (Hrsg.). Theologie der Religionen. Positionen und Perspektiven evangelischer Theologie. Neukirchen-Vluyn: Neukirchener Verlag, 2005, p. 107-120; BERNHARDT, R. Ende des Dialogs? Die Begegnung der Religionen und ihre theologische Reflexion. Zürich: Theologischer Verlarg Zürich, 2005; HEIM, S. M. The Depth of the Riches: A Trinitarian Theology of Religious Ends. Grand Rapids: Wm. B. Eerdmans Publishing Co., 2001; HEIM, S. M. Salvations: Truth and Difference in Religions. Maryknoll: Orbis Books, 1995. See also KNITTER, P. F. Introducing Theologies of Religions, p. 173-202.

5 THATAMANIL, J. J. The Immanent Divine: God, Creation, and the Human Predicament. An East-West Conversation. Minneapolis: Fortress Press, 2007. See also KNITTER, P. F. Introducing Theologies of Religions, p. 202-215.

6 See HICK, J. An Interpretation of Religion: Human Responses to the Transcendent. New Haven: Yale University Press, 1989; HICK, J. God has many Names. Philadelphia: The Westminster Press, 1982.

7 HICK, J. An Interpretation of Religion, p. 236.

8 See HICK, J. Auf dem Weg zu einer Philosophie des religiösen Pluralismus. In: Gott und seine vielen Namen. Frankfurt am Main: Lembeck Otto GmbH, 2001, p. 97-126, here p. $113 \mathrm{ff}$. 
religious difference 9 . Differences become insignificant in his model. Thus, it is necessary to develop Hick's model further. Two thoughts are important for these further conceptions: on the one hand, the positive acknowledgement of non-Christian religions, and on the other, the consideration that religions may not be best understood as answers to a Real "an sich", but rather from the perspective of the particular religion itself. More precisely, what follows from these reflections is the model of a mutual inclusivism ${ }^{10}$.

This indicates a whole network of different religious points of view in an interreligious dialogue. Thus, the task of a Christian theology of religions is to describe its relation to other world religions by means of interpretations of the Christian religion itself. The doctrine of Trinity could be suitable for this task, inasmuch as it connects the revelation of God with the special revelation of Jesus Christ ${ }^{11}$. This model of mutual inclusivism also wants to contribute to a culture of tolerance, but from the point of view within one's own religion. The difficulty that we might see in mutual inclusivism consists in the question of how to avoid a relationship of dependence of non-Christian religions as a result of describing Christianity's relationship to other religions in terms of a Christian doctrine of Trinity.

Over the last years, all the difficulties of the pluralistic model, as well as those of the new model of inclusivism, have resulted in a change of basis for the theology of religions, and a bidding farewell

LEUZE, R. Gott und das Ding an sich - Probleme der pluralistischen Religionstheorie. Neue Zeitschrift für Systematische Theologie und Religionsphilosophie, vol. 39, Issue 1, 1997, p. 42-64; KIPPENBERG, H. G.; STUCKRAD, K. Religionswissenschaftliche Überlegungen zum religiösen Pluralismus in Deutschland. Eine Öffnung der Perspektiven. In: LEHMANN, H. (Hrsg.). Multikulturalität im vereinten Europa. Historische und juristische Aspekte. Göttingen: Wallstein Verlag, 2003, p. 145-162, here p. 149ff; GRÜNSCHLOß, A. Der eigene und der fremde Glaube. Studien zur interreligiösen Fremdwahrnehmung in Islam, Hinduismus, Buddhismus und Christentum. Tübingen: J. C. B. Mohr (Paul Siebeck), 1999, p. 277ff.; BERNHARDT, R. Der Absolutheitsanspruch des Christentums. Von der Aufklärung bis zur Pluralistischen Religionstheologie. Gütersloh: Gütersloher Verlagshaus Gerd Mohn, 1990, p. 199ff.

10 BERNHARDT, R. Der Absolutheitsanspruch des Christentums. Von der Aufklärung bis zur Pluralistischen Religionstheologie; BERNHARDT, R. Protestantische Religionstheologie auf trinitätstheologischem Grund, p. 107-120.

11 See BERNHARDT, R. Trinitätstheologie als Matrix einer Theologie der Religionen. Ökumenische Rundschau, 49, 2000, p. 287-301; BERNHARDT, R. Protestantische Religionstheologie auf trinitätstheologischem Grund, p. 107-120. 
to the global theories connected with them in the three-fold system of exclusivism, inclusivism and pluralism. Since the 90s of the last century, especially in the United States of America, comparative theologies have been conceived as alternatives to the previous theology of religions ${ }^{12}$. They all want to stress more strongly the differences between religions and want to shift dealings with the religions, as a whole, into discussions of special religious fields. "Second, in lieu of encompassing theological theories based on claims for or against a universal religious experience, comparative theology should proceed by means of limited case studies in which specific elements of the Christian tradition are interpreted in comparison with elements of another religious tradition ${ }^{13}$ ". And in fact, that represents a continuation in comparative theology, since, by doing without global judgements in theology of religions, the differences between religious traditions can be better perceived than in the previous theology of religions.

Nevertheless, the problem of a comparative theology consists of two aspects in particular: firstly, in making a normative judgement between religious traditions, since a comparative theology does so no differently than the previous theology of religions, and secondly, there is the question whether a comparative theology really can do without universal categories, as several comparative theologians propose. The renunciation of universal categories could become a misunderstood empiricism.

Summing up, we can say that the contemporary debate is characterized by three problems: first of all, pluralism does not seem capable of perceiving the independence and special qualities of religions; secondly, mutual inclusivism seems to dissolve the independence of other religions and thereby to absorb them; thirdly, comparative theology seems

12 See NEVILLE, R. C. Behind the Masks of God: An Essay Toward Comparative Theology. Albany: State University of New York Press, 1991; CLOONEY, F. X. Comparative Theology: A Review of Recent Books (1989-1995). Theological Studies, vol. 56, 1995 , p. 521-550; CLOONEY, F. X. Theology after Vedanta: An Experiment in Comparative Theology. Albany: State University of New York Press, 1996; FREDERICKS, J. L. A Universal Religious Experience? Comparative Theology as Alternative to a Theology of Religions. Horizons, vol. 22, 1995, p. 67-87; FREDERICKS, J. L. Faith among Faiths: Christian Theology and Non-Christian Religions. Mahwah: Paulist Press, 1999.

13 FREDERICKS, J. L. A Universal Religious Experience? Comparative Theology as Alternative to a Theology of Religions, p. 83. 
to have no answer to the question of normative judgement of religions and religious traditions.

\section{Paul Tillich's Theology of Religions}

Tillich was constantly working on the problems of the history of religions for a modern theology ${ }^{14}$. In 1963, in his Bampton Lectures, he gave a detailed description of the problem of the encounter of Christianity with the non-Christian religions. These lectures develop a theory of a modern history of religions. Tillich connects the analysis of the encounter of world religions with considerations from the philosophy of religion and the theory of modernization, which should reflect the transformation of religion in the Modern Age. There are three important aspects for the contemporary theology of religions debate: at first, we have to name the complexivity of interreligious encounters ${ }^{15}$. There is no uniform attitude of Christianity in the encounter with other religions. Not only the historical religions themselves, but also their encounters are highly complex. It follows that it is not possible to reduce the relation of Christianity to the non-Christian religions to a tripartite scheme of exclusivism, inclusivism, and pluralism. Moreover, the encounter of religions is subject to historical change. Tillich does not understand this changing as the development from exclusivism to pluralism, as Hick does, but only as a dialectical relation of rejection and acceptance ${ }^{16}$. This relation is reflected within Christianity itself and its theology ${ }^{17}$. The principle of judgement is also a dialectical union of reciprocal rejection and acceptance that stands in the place of a total rejection of non-Christian religions by Christianity and of the hopeless effort of making distinctions between value or worth among religions ${ }^{18}$. On this methodological basis, Tillich determines the relation between Christi-

14 TILLICH, P. Die religionsgeschichtliche Konstruktion in Schellings positiver Philosophie, ihre Voraussetzungen und Prinzipien. In: HUMMEL, G.; LAX, D. (Hrsg.). Ergänzungsund Nachlaßbände zu den Gesammelten Werken von Paul Tillich. Bd. IX: Frühe Werke. Berlin; New York: Walter de Gruyter GmbH \& Co. KG, 1997, p. 156-272. See also SCHÜßLER, W. Im „Rhythmus von Kritik, Gegenkritik und Selbstkritik“, p. 61-74.

15 TILLICH, P. Christianity and the Encounter of the World Religions, p. 302.

16 TILLICH, P. Christianity and the Encounter of the World Religions, p. 302.

17 TILLICH, P. Christianity and the Encounter of the World Religions, p. 307.

18 TILLICH, P. Christianity and the Encounter of the World Religions, p. 301. 
anity and non-Christian religions to be a dialectical unity of mutual rejection and acceptance.

The second argument is of a quite religious theoretical nature and requires Tillich's determination of the relation of theology and philosophy of religion as an interrelation. Tillich's theology of religions is a differentiated acceptance of other religions from the point of view of Christianity. He understands the relation between Christianity and non-Christian religions as dialectical determination and summarizes it in the principle of conditional exclusiveness ${ }^{19}$. However, it represents a further determination of the dialectical relation between religions and a re-formulation of his concept of religion.

Two moments are constitutive for Tillich's conception of conditional exclusiveness. On the one hand, religious certainty is always concrete and historically determined. In Christianity it refers to Jesus Christ. On the other hand, in his concept of religious certainty, Tillich includes the differentiation of his double concept of religion. Religious certainty exists in form of concrete religions and cannot not be distilled from them. However, in a certain way, it is also independent from these forms. The depth of religious experience depends on how those forms are able to express the dialectics of religious consciousness. Thus, it is the principle of conditional exclusiveness that which determines the attitude of Christianity to the world religions as a dialectical union of rejection and acceptance. It neither means a wholesale rejection nor a wholesale affirmation of non-Christian religions. Tillich connects acknowledgement or recognition of other, strange religions with a critical reflection of Christianity itself ${ }^{20}$. This point now names the third aspect of Tillich's theology of religions that offers true progress for the contemporary theology of religions discussion: that is, the construction of the history of religions, which I want to sketch next.

Tillich's theology of religions goes out from one's own religious certainty and goes on to an encounter with other religions. For the structuring of the encounter of two religions, Tillich develops a typology of forms of religions on the basis of judgement of non-Christian

19 TILLICH, P. Christianity and the Encounter of the World Religions, p. 302.

20 See TILLICH, P. Christianity and the Encounter of the World Religions, p. $318 \mathrm{ff}$. [IV. Christianity Judging Itself in the Light of Its Encounter with the World Religions.] 
religions on the part of Christianity as a dialogue. "Such an attempt is perhaps the most difficult one in the comparative study of religions, but if successful it is the most fruitful for the understanding of the seemingly incomprehensible jungle, which the history of religion presents to the investigating mind ${ }^{21}$ ". Religious types result from the concept of religion and represent its internal building components ${ }^{22}$. Tillich's contribution to the present theology of religions debate may be seen in three parts. First of all, the construction of types of the history of religion is indispensable for the research of the science of religion. Without general concepts, the science of religion becomes a misunderstood empiricism. Secondly, Tillich speaks about types and this shows that it is not possible neither to construct a real, objective history of religion nor a gradual, higher development of the history of religion ${ }^{23}$.

But another, third aspect is more important, that is, the potential comparison of religions by means of these types. Tillich's typology of ethical and mystical elements, which are contained in every religious act, aims at cognition of that which is one's own within strange religions, and that which is other in the self, the own. "If the Christian theologian discusses with the Buddhist priest the relation of the mystical and the ethical elements in both religions and, for instance, defends the priority of the ethical over the mystical, he discusses at the same time within himself the relationship of the two in Christianity. This produces (as I can witness) both seriousness and anxiety ${ }^{24 "}$.

I conclude that theology of religions, just as much as interreligious dialogue, describes a discussion of that which is particular to one's own religion in the light of the religious Other. Furthermore, it serves to deepen an understanding of one's own religious convic-

21 TILLICH, P. Christianity and the Encounter of the World Religions, p. 310.

22 See TILLICH, P. Christianity and the Encounter of the World Religions, p. 311: "While specific religions, as well as specific cultures, do grow and die, the forces which brought them into being, the type-determining elements, belong to the nature of the holy and with it to the nature of man, and with it to the nature of the universe and the revelatory self-manifestation of the divine".

23 See TILLICH, P. Christianity and the Encounter of the World Religions, p. 311. "In terms of this method, for example, it would be impossible to call Christianity the absolute religion, as Hegel did, for Christianity is characterized in each historical period by the predominance of different elements out of the whole of elements and the polarities which constitute the religious realm".

24 TILLICH, P. Christianity and the Encounter of the World Religions, p. 311. 
tion and understanding and, in the end, results in acceptance of nonChristian religions. I refer to such a form of the theology of religions as hermeneutics of difference and I think it is more constructive than the previous debate, which is orientated by the tripartite scheme of the theology of religions. The hermeneutics of difference, firstly, makes possible a differentiated idea of highly complex encounters of worlds of religious symbols. Secondly, it reflects every description of religion from a certain point of view. And, finally, it is able not only to grasp religious worlds of symbols analytically and to interpret them, but also to subject them to a normative reflection. Tillich himself sees the normative telos of the history of religion in the religion of the concrete spirit ${ }^{25}$.

\section{Theses: Religious Pluralism and Theological Theories of Religion}

As an overview of the theology of religions debates over the last few years makes clear, the religious and cultural pluralism of modern society has found expression also in their theoretical descriptions. A multiplicity of theological conceptions of religion corresponds to the plurality of pieties. By way of conclusion, in the form of six theses, I would like to pursue the question of which consequences are to be drawn from what has been presented so far for a reflection on and treatment of religious pluralism within theology.

\section{Thesis 1: Also within theology, there can only be plural descriptions} of religious pluralism or of modern society. This is already the case for methodological reasons.

Theology has to acknowledge religious and cultural pluralism as the presupposition and basis of its description of religion. It constitutes the horizon of all theology in the modern era. This means, however, that there can be neither a final interpretation nor a single, decisive theory of religious pluralism. Therefore, theologies of the religious situation necessarily appear in the plural. There can be no sole correct or true interpretation. How could such an allegedly "true interpretation" even begin to substantiate itself? However, this does not mean that there are no arguments by which theories of religion can be designated ap-

25 See TILLICH, P. The Significance of the History of Religions for the Systematic Theologian, p. 437. 
propriate. Not every theology of religious pluralism does it justice. Theological concepts of religion that level off the diversity of religions and of religious forms are unsuited for describing the religious culture of modernity.

\section{Thesis 2: An appropriate description of religion has to include the participant perspective.}

As the debates of the last few years have made clear, theological reflection on religious pluralism cannot be done in abstraction from the perspective of the participant. Theologies of religion, like the pluralistic one, remove the participant perspective from the concept of religion and dissolve the historical religions into a comprehensive, abstract concept. In this respect, both the new inclusivism and the comparative theologies signify a continuation of the debate. Religion exists solely in its individual performance and symbolic self-presentation. Religion cannot be understood independently of its performance - for instance, as a fixed truth or a salvation at hand. Yet, religion can also not be functionally determined. In those theories that abstract from the self-understanding of the agents, it is the theorist who decides whether or not religion is present. However, over against substantialist and functionalist theories, religion is to be understood as a historically developed, human self-understanding, which describes itself as such. Religion is not an essential, anthropological feature in any way constitutive of the human. Rather, it emerges underivably as a mode of human self-understanding by taking up and transforming historically handed-down forms. The religious contents emerge simultaneously with the subject of religion. For this reason, universal, anthropological concepts of religion - but not a concept of religion as such - need to be eschewed in the theological description of religious pluralism.

\section{Thesis 3: The task of a theological theory of religious pluralism does not consist in an explanation of the diversity of religions.}

The theological treatment of religious pluralism in the form of pluralistic theologies of religion and their continuance in the conception of a mutual inclusivism have made clear that an explanation of religious pluralism is not at all possible. In the models discussed, either 
historical religions are relativized with reference to a superordinate meta-perspective or the non-Christian families of religion are coopted through a Christian-theological substantiation of them into one's own internal perspective. As it were, the attempt at an explanation of religious pluralism turns dialectically into its opposite. The pluralism turns out to be monism and the new inclusivism turns out to be superiorism.

However, the question whether there is an absolute religion does not at all arise in the concrete religious act, that is, in the performance of human self-understanding. Communication presents itself with certainty in symbolic forms. The problem, whether there are one or more absolute religions, only becomes an explicit topic at the level of theological reflection. Yet, there also, it is unanswerable ${ }^{26}$. Neither the history of religions nor a comparison of religions can provide an answer to this question. For, by what rule or criteria could the problem in question even be decided? Such rule or criteria always originate from a specific religious culture and, as such, cannot be universalized. There is no theology in the world that can provide an explanation for the truth or validity of some or all religions.

\section{Thesis 4: The task of systematic theology does not consist in provid- ing an explanation of the Christian religion.}

The object of systematic theology is the Christian religion. It presents, in a reflective mode, the religious performance and self-description of the Christian religion. As a matter of fact, systematic theology interprets the Christian religion. However, it does not establish it. Every attempt to define religion necessarily turns out to be circular. They always take up, as fundamental for religion, aspects that originate in the religious tradition in which the religious theorist stands. Systematic theology brings this circle up to the level of methodological awareness and describes religion as a historically developed form of human selfexpression. In this way, theology interprets and structures the connection between individual certainty and its symbolic self-expression. This,

26 Cf. FISCHER, J. Christlicher Wahrheitsanspruch und die Religionen. In: DANZ, C.; KÖRTNER, U. H. J. (Hrsg.). Theologie der Religionen. Positionen und Perspektiven evangelischer Theologie, p. 187-203. 
however, is the topic located behind the question of the absoluteness of a religion.

Systematic theology treats this topic by reflecting on the tension between historical dependency and the transformation of its contents. Religion, including the Protestant Christian one, exists merely as the diverse, symbolic self-expressions that describe themselves as religion. The religious contents symbolize, as it were, the way a symbolically communicated self-understanding functions and how a self - by means of those contents - makes reference to itself and, in doing so, produces itself as such in the first instance, in a symbolic self-expression. As the appropriation of already pre-given symbolic forms, the performance of religion described by systematic theology is simultaneously the production of those forms ${ }^{27}$. As it now becomes clear, there can only be piety and its presentation in the plural.

\section{Thesis 5: Theological theories of religion interpret religious com- munication, which only appears in the plural.}

It cannot be the task of a systematic theology to establish the validity of other or all religions. What, then, is the function of theology? Theology finds other religions - just as it does Christianity in its diverse denominations - as always already being there. As such, they are to be recognized and, if need be, criticized, as one's own religion. The theological treatment of non-Christian religions aims at the exploration of one's own religion in the horizon of another's. Religious self-understanding can only be presented in symbolic forms that are already integrated in a particular culture. This connection is the object of theological reflection on religion. Systematic theology addresses this connection in Christianity as well as in other religions and nonreligious areas of modern society. In this way, it makes a contribution to the deeper understanding of the Christian religion itself and its

27 Cf. WITTEKIND, F. Dogmatik als Selbstbewusstsein gelebter Religion. Zur Möglichkeit theologiegeschichtlicher Beschreibung der reflexiven Transformation der Religion. In: DANZ, C.; DIERKEN, J.; MURRMANN-KAHL, M. (Hrsg.). Religion zwischen Rechtfertigung und Kritik. Perspektiven philosophischer Religion. Frankfurt am Main: Peter Lang GmbH; Internationaler Verlag der Wissenschaften, 2005, p. 122-152, especially p. 149. 
transformation-dynamics against the backdrop of changing cultural and social life-worlds.

If in its description of the religious situation systematic theology does not proceed on the basis of an anthropologically universal concept of religion, then what is to be determined as religion can only result from the analysis of the concrete phenomena. As the theology of religion, theology works on the concept of religion. As a result, it has to be constantly broadened and corrected, inasmuch as religion is not otherwise substantially pre-given, but merely exists as a performance of symbolic self-expression that refers to itself as religion.

\section{Thesis 6: The criterion for judging religious pluralism lies in the reflexive self-transparency of the religious performance.}

Theology does not only serve to describe the religious act. Its task is also that of a normative determination of the essence of Christianity. This also is not simply present as a well-defined object, but exists only as a historically bound and mutable self-description. Thus, a normative judgment of the religious life-world of modernity can take place neither by recourse to revealed scripture nor by recourse to a universal religious concept of reason. The historical development of modernity has dissolved both of these. Only the reflexive self-transparency of that act, in which the subject emerges simultaneously with its contents, can function as a criterion. Religious traditions have to be measured against the self-awareness of finite freedom as finite freedom ${ }^{28}$.

\section{Bibliography}

BERNHARDT, Reinhold. Der Absolutheitsanspruch des Christentums. Von der Aufklärung bis zur Pluralistischen Religionstheologie. Gütersloh: Gütersloher Verlagshaus Gerd Mohn, 1990.

. Trinitätstheologie als Matrix einer Theologie der Religionen. Ökumenische Rundschau, 49, p. 287-301, 2000.

. Protestantische Religionstheologie auf trinitätstheologischem Grund. In: DANZ, Christian; KÖRTNER, Ulrich H. J. (Hrsg.). Theologie der Religionen. Positionen und Perspektiven evangelischer Theologie. Neukirchen-Vluyn: Neukirchener Verlag, 2005, p. 107-120.

28 I express my gratitude to my wife, Uta-Marina Danz, for translating this paper. 
. Ende des Dialogs? Die Begegnung der Religionen und ihre theologische Reflexion. Zürich: Theologischer Verlarg Zürich, 2005.

CLOONEY, Francis X. Comparative Theology: A Review of Recent Books (1989-1995). Theological Studies, vol. 56, p. 521-550, 1995.

. Theology after Vedanta: An Experiment in Comparative Theology. Albany: State University of New York Press, 1996.

DANZ, Christian. Einführung in die Theologie der Religionen. Münster; Wien: LIT Verlag, 2005.

Die Deutung der Religion in der Kultur. Aufgaben und Probleme der Theologie im Zeitalter des religiösen Pluralismus. Neukirchen-Vluyn: Neukirchener Verlag, 2008.

FISCHER, Johannes. Christlicher Wahrheitsanspruch und die Religionen. In: DANZ, Christian; KÖRTNER, Ulrich H. J. (Hrsg.). Theologie der Religionen. Positionen und Perspektiven evangelischer Theologie. Neukirchen-Vluyn: Neukirchener Verlag, 2005, p. 187-203.

FREDERICKS, James L. A Universal Religious Experience? Comparative Theology as Alternative to a Theology of Religions. Horizons, vol. 22, p. 67-87, 1995.

. Faith among Faiths: Christian Theology and Non-Christian Religions. Mahwah: Paulist Press, 1999.

GRAF, Friedrich Wilhelm. Die Wiederkehr der Götter. Religion in der modernen Kultur. München: Verlag C. H. Beck, 2007.

GRÜNSCHLOß, Andreas. Der eigene und der fremde Glaube. Studien zur interreligiösen Fremdwahrnehmung in Islam, Hinduismus, Buddhismus und Christentum. Tübingen: J. C. B. Mohr (Paul Siebeck), 1999.

HEIM, S. Mark. The Depth of the Riches: A Trinitarian Theology of Religious Ends. Grand Rapids: Wm. B. Eerdmans Publishing Co., 2001.

Books, 1995.

. Salvations: Truth and Difference in Religions. Maryknoll: Orbis

HICK, John. An Interpretation of Religion: Human Responses to the Transcendent. New Haven: Yale University Press, 1989.

. God has many Names. Philadelphia: The Westminster Press, 1982. . Auf dem Weg zu einer Philosophie des religiösen Pluralismus. In: Gott und seine vielen Namen. Frankfurt am Main: Lembeck Otto GmbH, 2001, p. 97-126.

KNITTER, Paul F. Introducing Theologies of Religions. Maryknoll: Orbis Books, 2002. 
JAMES, Robison B. Tillich and World Religions. Encountering other Faiths Today. Macon: Mercer University Press, 2003.

KIPPENBERG, Hans G.; STUCKRAD, Kocku von. Religionswissenschaftliche Überlegungen zum religiösen Pluralismus in Deutschland. Eine Öffnung der Perspektiven. In: LEHMANN, Hartmut. (Hrsg.). Multikulturalität im vereinten Europa. Historische und juristische Aspekte. Göttingen: Wallstein Verlag, 2003, p. 145-162.

LEUZE, Reinhard. Gott und das Ding an sich - Probleme der pluralistischen Religionstheorie. Neue Zeitschrift für Systematische Theologie und Religionsphilosophie, vol. 39, Issue 1, 1997, p. 42-64.

NEVILLE, Robert Cummings. Behind the Masks of God: An Essay Toward Comparative Theology. Albany: State University of New York Press, 1991.

RIESEBRODT, Martin. Die Rückkehr der Religionen. Fundamentalismus und der „Kampf der Kulturen“. München: Verlag C. H. Beck, 2000.

SCHÜßLER, Werner. Im „Rhythmus von Kritik, Gegenkritik und Selbstkritik“. Paul Tillich zum Absolutheitsanspruch des Christentums und zum interreligiösen Dialog. Trierer Theologische Zeitschrift, 116, 2007, p. 61-74.

STENGER, Mary Ann. Christ Jesus - Centre of History for Whom? Exploring Tillich's Christology for Developing a Critical Pluralism. In: HAIGIS, Peter; HUMMEL, Gert; LAX, Doris. (Hrsg.). Christus - Mitte der Geschichte!? Beiträge des X. Internationalen Paul Tillich-Symposions Frankfurt/Main 2004. Berlin: LIT Verlag, 2007, p. 257-269.

THATAMANIL, John J. The Immanent Divine: God, Creation, and the Human Predicament. An East-West Conversation. Minneapolis: Fortress Press, 2007.

TILLICH, Paul. Christianity and the Encounter of World Religions. In: SCHARLEMANN, Robert P. (Hrsg.). Main Works - Hauptwerke. Band 5: Religiöse Schriften. Berlin; New York: Walter de Gruyter; Evangelisches Verlagswerk, 1988, p. 291-325.

. The Significance of the History of Religions for the Systematic Theologian. In: HUMMEL, Gert. (Hrsg.). Main Works - Hauptwerke. Band 6: Theologische Schriften. Berlin; New York: Walter de Gruyter; Evangelisches Verlagswerk, 1992, p. 431-446.

. The Encounter of Religions and Quasi-Religions. Lewiston; Queenston; Lampeter: Edwin Mellen Press, 1990.

. Die religionsgeschichtliche Konstruktion in Schellings positiver Philosophie, ihre Voraussetzungen und Prinzipien. In: HUMMEL, Gert; LAX, Doris. (Hrsg.). Ergänzungs- und Nachlaßbände zu den Gesammelten Werken von Paul Tillich. Bd. IX: Frühe Werke. Berlin; New York: Walter de Gruyter GmbH \& Co. KG, 1997, p. 156-272. 
WITTEKIND, Folkart Dogmatik als Selbstbewusstsein gelebter Religion. Zur Möglichkeit theologiegeschichtlicher Beschreibung der reflexiven Transformation der Religion. In: DANZ, Christian; DIERKEN, Jörg; MURRMANNKAHL, Michael. (Hrsg.). Religion zwischen Rechtfertigung und Kritik. Perspektiven philosophischer Religion. Frankfurt am Main: Peter Lang GmbH; Internationaler Verlag der Wissenschaften, 2005, p. 122-152. 